\title{
Investigating Attitudes of EFL Learners Towards Standard English (SE) and Pakistani English (PE) at a Public Sector University, Sindh Jamshoro
}

\author{
Moomal Raza Bhurt \\ MS Scholar, Mehran University of Engineering \& Technology, Jamshoro \\ Syed Waqar Ali Shah \\ Lecturer, Mehran University of Engineering \& Technology, Jamshoro \\ Dr Habibullah Pathan \\ Associate Professor, Mehran University of Engineering \& Technology, Jamshoro \\ Chahat Batool Pirah Sapna Sanam \\ MS Scholar, Mehran University of Engineering \& Technology, Jamshoro
}

\begin{abstract}
This study deals with the attitudes of EFL learners towards accent of Standard English and Pakistani English at public sector University Jamshoro. There are not much studies have done in Pakistani context, in order to investigate the attitudes of EFL learners towards accent of Pakistani English and Standard English. University of Sindh was selected as site of the study. Quantitative research method was used for this study and the close ended questionnaire was adopted from Parveen and Mehmood (2013) was used as a tool of the study. The random selection of the participants was done. They participants were 200 in number and they were the students of Institute of English Language and Literature, University of Sindh, Jamshoro. The data was collected online through google form. The data was analyzed using statistical methods. SPSS version 22 was employed to carry out the statistical operations. Quantitative data was analyzed through SPSS to draw mean, median mode and percentages for each item in the questionnaire. It was found that EFL learners' attitude towards the accent of Standard English and Pakistani English was positive. If one is acquiring a standard accent of English as an additional ingredient to one's linguistic knowledge that would be okay in multiple concerns. On the other hand if it is being given exaggerated significance and is learned discriminatively, that would be matter of great debate around the globe to cease language crisis.
\end{abstract}

Keywords: Attitudes, Quantitative, EFL learners, Standard English, Pakistani English, Accent

DOI: $10.7176 / J L L L / 83-04$

Publication date: November $30^{\text {th }} 2021$

\section{Introduction}

English language is official language of Pakistan, it is the main reason that many of the institutes, in Pakistan, demand the fluency in English language. Though, the basic education should be given in mother tongue or in native language, the importance of English Language cannot be degraded. English, as a foreign language (ESL), is also considered as a Second Language (ESL).

An attitude is individualized, but there is origin of collective behavior. Attitude is something a person has that determines those habits or supports them. While an attitude is a psychological hypothetical construct, it touches the truth of the existence of language. In the discussion of bilingualism, Baker (1988) emphasizes the value of attitudes. Attitudes are predispositions that are acquired, not genetic, and are likely to be relatively stable; they appear to continue. Attitudes, however, are conditioned by experience; therefore, in bilingualism, attitude adjustment is an important notion. Attitudes range from being positive to being unfavorable. Attitudes are dynamic constructs; for example, positive and negative emotions, such as a language situation, can be attached to it (Baker, 1988, pp. 112-115). Language varies from person to person, state to state and country to country. The attitude of language depends on its tone, pronunciations, accent, speech style and dictionary or vocabulary. Language is a vast term. The universe is incomplete without it. Therefore many variations may be considered in this regard. There are different variables used to either improve or to impair the attitudes of language. The verbal directions used for language, suggest the context of the language attitude and its comprehensive approach and outlook to design it (Garrett, 2007).

Language attitudes are referred to as collection of vast empirical studies which relate to social meanings of various competing languages and their dialects spoken in any context (Lambert, 1965; Giles et al. 1975). There are various perspectives to see the language attitudes of any speech community towards different languages and varieties. These perspectives are sociological, sociolinguistic and socio-psychological in nature. In sociological 
terms, researchers are interested in using questionnaires and interviews as required data collection methods to understand the symbolic values of languages in any social and situational context. The sociolinguistic trend started with the work of Labov $(1966,1972)$ who was more interested in investigating the relationship between specific linguistic features and the speech group. However, in socio-psychological phase, the focus was paid on the individual's disposition or display of attitudes towards particular varieties and the speech groups. The social psychologists are more interested in how individuals treat the languages than the social factors to see relation between the linguistic features and the speech group. The socio-psychological process is therefore more personfocused than socially centered (Lambert, 1965; Giles et al. 1975). The present study is situated in third phase of attitudinal studies on language i.e. socio-psychological phase. Pakistani English is one of the broadly used postcolonial variety of world English. In Pakistan, Britain originated English is used, also known as Pakistani English. The Pakistani variety of English is impacted by Both Pakistani languages and indigenous cultures in Pakistan, as well as American English brought in through the media. The grammatical and lexical characteristics of Pakistani English are quite different from those of Standard American and Standard British English. The variety of English spoken in Pakistan is distinctive than the variety of English used in other Parts of world, so called Pakistani English (PE). According to Rehman (1990) there are four sub-varieties of Pakistani English for instance Acrolect English, Mesolect English, Basilect English and Anglicised English. Pakistani English is relatively recent, so most people are not aware of it. The norm they use in their correspondence is not a "native speaker" variant (Baumgardner 1995). There are some special features of Pakistani variety: it has its own lexical and grammatical objects (Baumgardner 1995), Urdu borrowing, and verbosity of expression (Husain 1992). The Pakistani variety has its own sociolinguistic contours, such as the new use of old words and the wordy Pakistani English (Talaat 2003). On the other hand the western belief is that the old ideals are reflected by the old words (Gorlach 1991; Talaat 2003). Whatever the traditional English pedagogical forms are in Pakistan, it is a fact that it has developed itself as a Pakistani variety. And now it is time to define and codify the official language, it is known as a valid variety (Mansoor 2002).

Standard English (SE) is considered as the correct, accurate and actual form of English. It has the ingredients of lexical elements, semantics characteristics, idiomatic expressions and other such pieces of languages attributions. Standard English is complete in its all sides and do not demand any kind of improvisation. SE is the real, accurate and reliable version of modern English (Rehman, 2020).

Native speakers use different dialect in foreign circumstances i-e global standard while their own dialect in their home country. Most of the accents are equally understandable but again it depends on the abilities of the speaker. Some accents are believed to be more admired than the others, but not within the accent itself, because there is no prestige in the listener's view. Several studies have shown that the quality and prestige evaluations of language varieties are based on the interpretation of their social connotations. The use of dialects and accents, for instance, will therefore be expressions of social choice that indicate an understanding of the rank and prestige that is given to the speakers of these varieties. There is no inherent aesthetic or linguistic advantage of a prestige standard language form over non-standard varieties. Reputation is typically the result of the transmission of social stereotypes from one generation to the next (Edwards, 1982, p. 21).

\subsection{Research gap}

Relatively various studies have recorded worldwide on the attitudes towards the language learning. There are few studies found in the context of Sindh, Pakistan to see the attitudes of EFL learners towards the spoken English of two different varieties i.e Pakistani English and Standard English. A significant deciding factor in this process is the attitude of students towards the two different varieties of English; hence, the current research was carried out to explore this phenomenon. This study is thus an attempt to fill this research gap in order to investigate the attitudes of EFL learners towards the Pakistani English and Standard English. Therefore, the present research is an effort to assess students' Attitudes towards the accents of two different varieties of English i.e Pakistani English and Standard English.

\subsection{Research Questions}

RQ1: What are the attitudes of EFL learners towards the accent of Standard English? RQ2: What are the attitudes of EFL learners towards the accent of Pakistani English?

\section{Literature Review}

Sim (2012) mentioned that Positive, negative or Natural can be the attitude towards a language. Positive attitude respondents believe that ethnic language is important for the survival of their group, negative feelings appear to forget the language, and the language is considered irrelevant to the current situation in various subjects. The reputation of a language can also be measured by taking the language attitudes of the group into consideration. The attitudes of youth and the position of the elderly are two elements of prestige in shift, but it is the attitude of youth that defines more shift to a specific group and language. The attitude therefore helps researchers to 
evaluate the change to a language.

Ahmed (2015) exposes that EFL learners' attitude towards Standard English may face different hinders. Different students from various universities who study, may need to learn English in order to write dissertation, reports or essays and work in seminars. Motivation is the basic thing in this regard. Interest is an important thing which may play a significant role in this regard.

Language learning is argued to be regarded as the foundation of human life. By learning the language, it will enable us to communicate our emotions, hopes and even our dreams. Language is the basic component of interaction for living being. Attitudes towards learning have a direct effect on the attitudes of learners and thus on their success. It has been argued that EFL learners with optimistic views about language learning appear to improve their attitudes towards language learning more positively. The goals to achieve Standard Language outcomes are basically difficult in its nature. Standard Language demands for the accuracy in its all aspects (Abidin et al, 2012).

Rehman (2020) mentioned that in different developing countries like Pakistan English language opted as a Second Language (ESL). This is the reason, however English language as ESL is non-native variety. Pakistan has opted many native words in Pakistani English. These words explain the same meaning as in the Urdu that is the national language of Pakistan. These words also indicate that English is the mixture of many languages. To prevail, the concept of advanced form, Pakistan has contributed such words in Pakistani English. Learning English language has become a rift and the need of an hour. English is a global language spoken widely in all over the world. This is the reason English language has some complexities which are difficult to comprehend for new learners. Not only EFL learners face hurdles regarding learning Pakistani English, Standard English also has complexities regarding the concerned problem. Pakistani English has included many words which are spoken same in all over the country. These words are spoken in English as same as in Urdu. The regional concept of speaking has also played a significant role in this regard (Joseph, 2004). The learners' feelings and emotions as an inevitable factor in language learning, plays an active role in this regard. Experiencing to learn Pakistani English has become a challenging task for EFL learners. An effective language learning output can be obtained through proper sequences. Recognition, passion, learning ability and pace has a great importance for concerned target (Bhatti et al, 2016).

\section{Research Methodology}

The present study aimed to conduct a quantitative survey with the EFL learners at a University of Sindh, Jamshoro in order to investigate their attitudes towards the accent of Pakistani English (PE) and Standard English (SE). The participants for the current study were randomly selected among the Bachelor (B.S.) students of Institutes of English Language and Literature, University of Sindh, Jamshoro. A questionnaire was adopted to achieve the Objectives of current study.

\subsection{Data Collection Tool and Procedure}

The current study used survey as a data collection tool and a close-ended questionnaire was used and adopted for the current study that was originally prepared by Parveen and Mehmood (20113) in order to measurement the attitudes learners towards the different English language accents. The questionnaire focused on 30 items concentrating on the attitudes towards the accent of Standard English. The responses of the participants were reported on the Likert 5 point scale. The researcher has administered the evaluation sheet (questionnaire) among 200 language learners through online google form.

\subsubsection{Participants}

This phase of the study included 200 participants from the University of Sindh Jamshoro. Besides, the ratio of male and female participants were maintained as per enrolment data of the concerned department of University, so it was feasible to find the participants using random sampling. The data was collected through online google form and the participants were also be ensured about their privacy and confidentiality of the recorded speech to be used only for research purpose in this study

\subsection{Data Analysis}

The present study employed these statistical techniques to infer the data in order to apply to wider population. (Cramer, 2003). The questionnaire data of the study was gathered and analyzed computationally through the Statistical Package for Social Sciences (SPSS, V.22) in terms of percentage. The measure of central tendency included mean, medians, and mode with a standard error of the mean. They enable us to summarize our data set with a single value, resulting in a more accurate representation of our data set. Likert scale ranging from $1=$ strongly agree $2=$ agree $3=$ Uncertain $4=$ disagree $5=$ strongly disagree was used to measure participants' level of agreements and disagreements for each variable in the questionnaire. The data analysis of questionnaire items was analyzed through descriptive statistics. 


\section{Findings and Discussion}

The results declared that, $96 \%$ of respondents said that they prefer to communicate in English and they enjoy speaking in English. 89\% respondents agreed with it that Pakistani English is a different variety and believed that it is distinct from Standard English. 73\% of participants agreed with it that English refers to Standard English accent. 85\% respondents understand the notion of Standard English and can tell the difference between Pakistani English and Standard English. 67\% respondents wanted to sound like Native speakers.

$84 \%$ respondents were very happy when they asked how they would feel when someone thought their accent sounded like a native speakers and they responded that they would feel that they have succeeded in English language learning when people thought like this about their accent. When speaking in a foreign context, $60 \%$ of students strongly agreed that they have an inferiority complex. Seventy seven percent of pupils believe that speaking Standard English is a prestigious skill. The concept of prestige and status is influenced by the element of standard and non-standard.

$74 \%$, on the other hand, prefer to devote more time to learning a standard accent. There is cultural pressure on accents, according to 75 percent of respondents, and 13 percent of students disagreed with it. 60 percent of students agree that a Standard English accent is necessary for international comprehension, and they are well aware that accent has a social component that influences their interactions with others. Furthermore, $60 \%$ of the respondents said they disagree or strongly disagree that learning an accent is more important than understanding a subject. Since language is mostly used for communication, 80 percent of students disagree that proper accent is more important than knowing structures.

The following question was asked to determine whether respondents thought accent was an issue or not: 'When you have problem in communicating in English, it is more likely because of a grammatical or pronunciation problem.' Accents are not a problem as long as they do not obstruct communication, according to $75 \%$ of students. Although $69 \%$ of the respondents feel that having a Standard English speaker as a teacher is preferable than having a PE speaker, $73 \%$ students responded that they expect their teachers to educate them with a Standard English accent. In this study, the participants showed no interest in keeping their accent as a marker of identity. It is not necessary to learn accents because it removes one's identity and origin, according to those who disagree or strongly disagree. Accents and identity are undoubtedly linked issues, but because they can communicate in their first language, learning another will have no impact on their identity.

\section{Conclusion}

The overview of the results depicts that, EFL learners attitude towards the accents of different varieties were positive. Their responses indicates that Language is the source of identity. However one speaker reflects his own identity and place of origin, regardless of language and English is not an exception. Therefore, as an English language learners, they felt free to speak in their own accent. To them, speaking or pronouncing words exactly in a manner like natives was not a big deal. Consequently, they enjoyed speaking as accurately as they could, to them clarity counts the whole thing.

Standard English has some prestigious status around the world, so the results show that apart from identity crisis, it would be better if one is having Standard English accent. However, in concern to identity crisis it must be in mind that all languages are equal and one's mother-tongue should be given more priority than a foreign language in home hours. In nut shell if one is acquiring a standard accent of English as an additional ingredient to one's linguistic knowledge that would be OK in multiple concerns. On the other hand if it is being given exaggerated significance and is learned discriminatively, that would be matter of great debate around the globe to cease language crisis.

\section{References}

1. Cohen, L., Manion, L., \& Morrison, K. (2002). Research methods in education. routledge.

2. Creswel, J. W. (2009). Research design: Qualitative, quantitative, and mixed methods approach. Los angeles: University of Nebraska-Lincoln.

3. Choi, Y. H., \& Lee, H. W. (2008). Current trends and issues in English language education in Asia. Journal of Asia TEFL, 5(2).

4. Jiménez, R. T., \& Rose, B. C. (2010). Knowing how to know: Building meaningful relationships through instruction that meets the needs of students learning English. Journal of Teacher Education, 61(5), 403-412.

5. Johnson, V. H. (2011). An examination of teacher perceptions of foreign language learning. Lamar University-Beaumont.

6. Kvist, C. (2014). Teachers' Perceptions of Second Language Learning and Teaching-A Comparison of Two Groups of English Teachers.

7. Lincoln, Y. S., \& Guba, E.G. (1985). Naturalistic inquiry. Beverly Hills, CA: Sage.

8. Paik, J. (2009). "Learning English, Imagining Global": The Narratives of Early English Education Experiences in South Korea. International Journal of Learning, 15(10). 
9. Pathan, H., Shahriar, A., \& Mari, M. (2010). Motivation for learning English in Pakistan. EFL Annual Research Journal, 12, 75-91.

10. Patil, Z. N. (2008). Rethinking the objectives of teaching English in Asia. Asian EFL Journal, 10(4), 227240.

11. Roy, A. K. (2019). The Attitudes of English Teachers Towards Their Classroom Teaching. research journal of social sciences, $10(2)$. 